\title{
Improving Student's Listening Skill Using Task- Based Approach in EFL Classroom Setting
}

\author{
Heri Kuswoyo, S.S., M.Hum \\ Faculty of Arts and Education \\ Universitas Teknokrat Indonesia \\ Bandarlampung, Indonesia \\ hery@teknokrat.ac.id
}

\author{
Achmad Yudi Wahyudin, S.Pd., M.Pd \\ Faculty of Arts and Education \\ Universitas Teknokrat Indonesia \\ Bandarlampung, Indonesia \\ Achmad.yudi@teknokrat.ac.id
}

\begin{abstract}
This research aimed to investigate the improvement of the studentse listening skill by using Task-Based learning Approach at higher school of foreign language Teknokrat in Lampung Province. To reach the goal, the research was conducted in two cycles; each cycle consists of three meetings. A number of research subjects were 35 students in the first semester majoring English literature in the 2016/2017 academic year. The instruments were observation, test, and questionnaire. The research findings showed that Task- Based Learning approach could improve the student's listening skills. They also gave a significant contribution in learning process of listening accurately and fluently.
\end{abstract}

Keywords: Task-Based Learning, Classroom Action Research (CAR), listening Skills

\section{INTRODUCTION}

One of the missions of the English Literature study program at higher school of foreign language Teknokrat aims at producing English literature scholars who are able to communicate professionally to serve the needs of global industry. The success of graduates is largely determined by a good learning process and the implementation of appropriate learning methods.

However, the facts proved that most lecturers still use the lecturing method, which is to convey the teaching materials only by continuous speech so that many students who are not interested with the explanation of lecturers. This occurs in one of the listening subjects where the student has a problem in listening skill. It is functional listening. This evidence is reinforced by the number of students who failed in one of the English Proficiency Test, especially the listening comprehension section.

This issue becomes the author"s concern since functional listening course is the basic requirement for other listening courses such as conversational listening, critical listening as well as academic listening. In their article, Rahbar \& Khodabakhsh (2013) revealed:

Listening comprehension ability is one of the most difficult ones to master, especially in an EFL context in which the students are not exposed to the natural speech of the native speakers and therefore are reluctant in attending listening classes.

This proves that listening ability is one of the most difficult skills to master especially for learners where English is as a foreign language. In addition, the difficulty of mastering listening skills may be due to the lack of a fun learning model or so-called PAIKEM, which is active, innovative, creative, efficient, and fun learning (Arikunto et al, 2015). Besides, the English Literature Study Program at higher school of foreign language Teknokrat also does not have teaching materials in the form of workbook for the subjects listening especially Functional Listening. For that reason, students do not have varied activities and result in boredom in the learning process.

The above problem is the underlying basis for the researcher to conduct a classroom action research (CAR), to solve the overarching problems occurred during listening class. CAR was choosen as an attempt to improve the student "s listening skills in Functional Listening course and it is expected that students will have the opportunity to communicate in the class rather than being dominated by their lecturer while speaking. Thus, students are not only forced to study but can enjoy the learning process.

Based on the aforementioned empirical and theoretical basis, this research formulates 1) what are the student's perception of task-based learning in functional listening class at higher school of foreign language Teknokrat? 2) Do listening skills in the functional listening class increase using task-based learning?

\subsection{Listening Skills}

\section{LITERATURE REVIEW}

Listening is a comprehensible oral language skill. Nunan (2003: 24) 'Listening is an active, purposeful process of making sense of what we hear. Language skills are often categorized as receptive or productive. 
Speaking and writing are the productive skills. Listening, along with reading, is a receptive skill '. Thus listening does not mean just listening to the sounds of the language but at the same time understand it. In the first language (mother tongue), we acquire listening skills through a process that we do not realize so we are not aware of the complexity of the process of acquiring the listening skill.

According to Tarigan (1997) there are two types of listening situations: interactive listening situations and non-interactive listening situations. Interactive listening occurs in face-to-face conversations and conversations on the phone or the like. In listening to this type we alternately do listening and gain an explanation, asking the other person to repeat what he or she is saying or maybe ask him to speak rather slowly. Then the examples of non-interactive listening situations are listening to radio, TV and movies, preaching or listening in ceremonial events. In such non-interactive listening situations, we cannot ask for an explanation from the speaker, cannot ask for the call to be slowed.

\subsection{Model in Listening Process}

There are several models that have evolved in explaining how the process of listening works. The known model is bottom-up and top-down models. This approach refers to the use of incoming data as a source of information about a message. This bottom-up approach starts from analyzing the messages received based on the organization of sounds, words, and sentences to the process of receiving meaning. Flowerdew \& Miller (2005: 24) 'according to this model of communication, the sender encodes a message, which passes along the communication channel in the form of a signal and is then decoded by the receiver'. Thus, this type of listening approach is seen as a process of message interpretation (decoding).

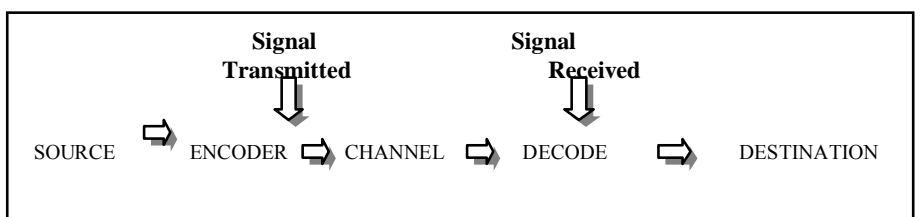

Figure 2.2.1 Concept of communication transmission (Flowerdew \& Miller, 2005)

A top-down listening approach refers to a process that describes background knowledge in understanding the purpose of a message. According to Flowerdew \& Miller (2005: 24), ,top-down models emphasize the use of previous knowledge in processing a text rather than relying upon the individual sounds and words'. In this approach, listeners are helped to understand the message and the spoken text with the help of other knowledge. There are several forms of background knowledge such as knowledge of the topic of a discourse, situation, contextual or knowledge that has become a memory for someone in the form of a scheme. In the top-down listening approach, prior knowledge has an important role because the initial knowledge can help the listener in understanding the listening. This type of approach is used by the listener if he has sufficient language knowledge and language background and if there are cues in the text that can activate the schemata.

\subsection{Task-Based Learning}

Task-based learning requires a comprehensive teaching approach in which student learning environments are designed so that students can investigate authentic problems including the deepening of material from a subject topic, and perform other meaningful tasks. Brown in Flowerdew \& Miller (2005: 14) "with this approach, students are asked to listen to what are described as "authentic" situations and "to do something" with the information". This approach allows students to work independently in constructing real products.

In project-based learning, students are given a task or complex projects, quite difficult, complete, but realistic and then provided with sufficient assistance in order for them to complete the task. In addition, the implementation of this task-based learning strategy encourages the growth of nurture competencies such as creativity, self-reliance, responsibility, self-trust, and critical and analytical thinking. Brown in Flowerdew \& Miller (2005: 14) 'the main idea behind a task - based approach to developing listening is the student become active listeners'

In addition, according to Spratt in Riana Sari (2012), task-based language teaching (TBLT) is one of communicative approach activities focus on the flow of discussion $\rightarrow$ assignments $\rightarrow$ presentation $\rightarrow$ focus on the form of language. The purpose of learning is that students can complete an assignment to produce "outcomes". One of the frameworks in the TBLT approach was prepared by Willis (1996: 52). The framework consists of the Pre-task, Task Cycle, and Language Focus stages.

At the pre-task stage, the lecturer begins with an initial discussion of the learning topics related to the student experience. In the tasks cycle stage, students do several tasks, such as listing, sharing personal experiences, problem solving, and creative tasks, both individually, in pairs, and in groups. At the language focus stage, lecturers and students jointly analyze the various forms of language in the assignment, and then students do the practice of completing the last assignment (outcome). In more details, these three stages can be seen in the picture below. 


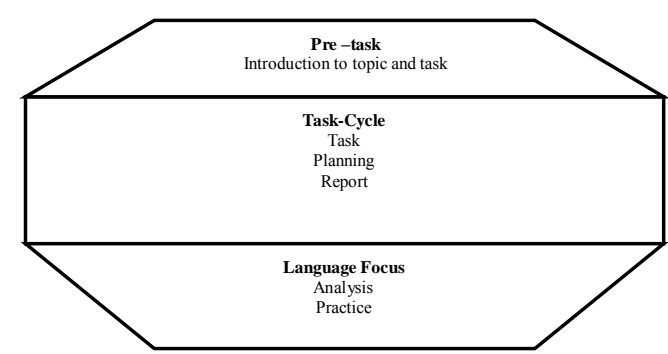

Figure 2.3. TBLT Framework by Willis (1996: 52)

Ruso (2007) argues TBLT encourages student's involvement and leads to significances improvements regarding their language performance". This explains that task-based English learning provides an interaction experience and improves learners' self-confidence so that English language skills are improved.

2.4 Concept of Task

Tasks are the main activities in the TBL method. This is because the task can increase the motivation of learners and improve learning. In addition, in TBL, the task requires the learner to use an authentic language, the task of varying formats and operations, the task of having a typical physical activity and the task of pairing and collaboration activities. (Richard \& Theodore, 2001: 229)

In his book (Brown in Flowerdew, J \& Miller, L, 2005) argues that the main idea behind a task - based approach to developing listening is that students become active listeners. This explains that the main idea in task-based learning is that learners can become more active. In the design of task-based learning there are at least six types of tasks that can be applied (Willis, 2004: 26-27). The types of tasks are: listing; ordering and sorting; comparing; problem solving; sharing personal experiences; and creative tasks.

\subsection{Previous Research}

Some previous studies that have been read by researchers are; Sarani, Behtash \& Arani (2014) in the journal "Gist Education and Learning Research Journal" entitled the effect of video-based tasks in the listening comprehension of Iranian Pre-intermediate EFL Learners. This study investigates the effectiveness of video-based learning in students in Iran. The results show that research using video-based learning has a very important effect in understanding authentic texts effectively.

The second previous study was taken from Nahavandi (2011) in a journal entitled the effect of task-based activities on EFL learners' reading comprehension. This research investigates the effectiveness of taskbased learning on students' reading skills. The author uses experimental methods in which students are given activities based on the task while the control class is not. There is a very different difference between the experimental class and the control class. While the last previous research is an article from Promruang, Jipada (2012) on his thesis entitled "The use of tasks based learning to improve English Listening and speaking abilities of Mattayomsuksa 1 students at Piboonprachasan School". This research investigates solutions for low motivated learning. The author uses interview techniques, questionnaires and diaries. The results show that student motivation increases.

The difference between current and past research lies in the type of skill being analyzed. The first study focuses only on video reality, whereas current research will focus its research on a more varied realia. Previous research is more dominant in discussing reading, writing and speaking skills than listening. Therefore research will now focus on listening skills. The things adopted by researchers is the technique of data retrieval and how data collection.

\section{METHODOLOGY \\ 3.1 Research Design}

The research approach that will be used in this research is classroom action research. This study is structured to solve a problem, tested in real situations by looking at flaws and strengths and making changes that serve as improvements. This remedial action is carried out by carrying out actions to seek answers to issues raised from daily activities in the classroom.

In this classroom action research, task-based learning methods will be used in a particular class selected by the authors in this study. In the implementation of this classroom action research will be used several methods such as, observation, recording, and questionnaires in the data retrieval.

The research procedure of this class consists of 2 cycles. Each cycle is carried out in accordance with the changes to be achieved, as it has been designed in the variables investigated. To be able to know the listening skills of the students, a diagnostic test is provided that serves as the initial evaluation (Pre-Test). Preliminary observations are made to be able to know the exact action given in order to minimize the error. From the evaluation and preliminary observation it can be determined that the action used to improve students' writing skills is through the use of task-based learning methods. Based on the initial reflection, this classroom action research is carried out by procedure (1) planning, (2) action implementation, (3) observation, and (4) reflection in every cycle. Explanation of the above cycle can be seen in chart 3.1 below. 


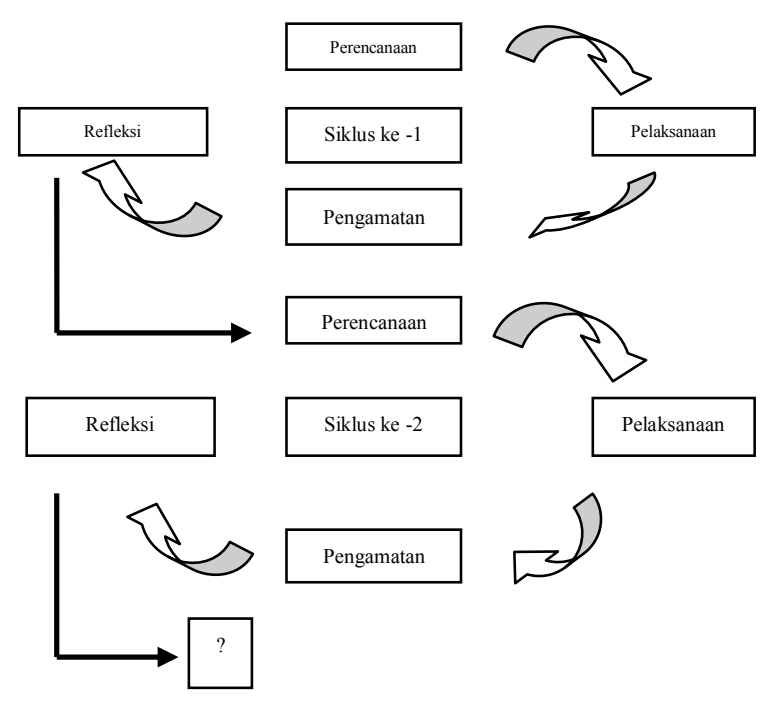

Figure 3.1 Action Research Cycle (Arikunto et al, 2015, p.42)

\subsection{Data Source}

This research conducted at higher school of foreign language Teknokrat Lampung on the program of English Literature academic year 2016/2017. The data source will be obtained in functional listening subject. The population was the first semester students which consist of 35 students. The data were obtained using quantitative data from learning outcomes and qualitative data consisting of learning program plan, data of observation result on learning implementation, and data of result of questionnaire by students.

\subsection{Data Collection Techniques and Data Analysis}

Method of data collection used in this research that is (1) data of student learning results. The data is taken by giving the test (Pre-Test and Post Test). Here are the results of the normality test in cycle I and cycle II:

Table 3.4 Tes Normalitas pada siklus I dan siklus II

\begin{tabular}{|c|c|c|c|c|c|c|}
\hline & \multicolumn{3}{|c|}{ Kolmogorov-Smirnov $^{\mathrm{a}}$} & \multicolumn{3}{|c|}{ Shapiro-Wilk } \\
\hline & Statistic & df & Sig. & Statistic & df & Sig. \\
\hline pretest & ,104 & 35 &, $200^{\star}$ &, 972 & 35 &, 512 \\
\hline posttest & 127 & 35 & 166 & ,970 & 35 & ,431 \\
\hline pretest2 & 137 & 35 & ,093 & ,965 & 35 &, 320 \\
\hline postest2 & 145 & 35 & , 061 & ,957 & 35 & 181 \\
\hline
\end{tabular}

Cycle I $=$ pretest-posttest

Cycle II= pretest2-postest 2

*) The data is considered normal since the significance of Kolmogrov-Smirnov test exceed $\alpha(0.05)$
Meanwhile, the way of data collection (2) is data about teaching-learning situation. At the time of implementation the action is taken by using observation sheet, and recording and (3) data about the relation between planning and implementation obtained from the plan of learning program and observation sheet.

The instrument of this research is the listening test given at the beginning of the research (pre-test) and at the end of each cycle (post-test), questionnaire, field note, observation sheet, and observation guideline. The success indicators of this classroom action research are based on product success and process success. The indicator of product success is seen from the improvement of the students' listening skill score which is getting the average score of 7; while the indicator of the success of the process seen from the learning process undertaken.

Validity of data in this study used two criteria. They are construct validity and content validity (Sugiyono, 2009: 177). Construct validity and Content Validity are implemented in the planning of Cycle I and Cycle II. The form is (1) by looking for learning skill listening that will be done like lecture material, learning steps, learning media to be used, and evaluation of learning skill of listening in form of résumé and (2) by conducting discussion with student about material the preparation of résumé that has not or has not been mastered by the students.

The results of this action study were analyzed in two ways. Data on the use of teaching methods of taskbased learning in learning are interpreted qualitatively, while the students' skill data in listening is interpreted quantitatively.

\section{RESEARCH FINDINGS AND DISCUSSION}

This chapter reports on the results achieved in a series of research activities conducted from February 2017 to August 2017 at higher school of foreign language Teknokrat

Lampung.

This research found two objectives to be achieved, that is what are the studente's perception about task-based learning and whether the listening skill increases with task-based learning. The data of research findings can be seen below. 


\subsection{Student's Perception on Task Based Learning}

The result of student's perception about Task Based Learning can be seen in the average form in the chart below:

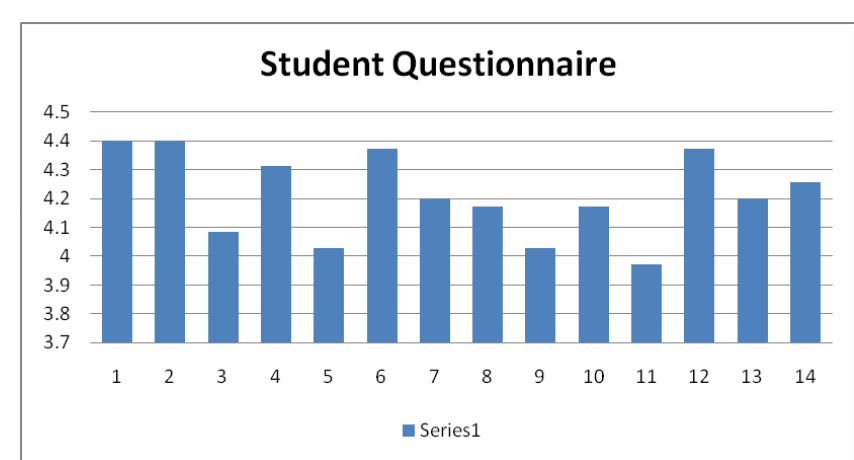

Chart 4.1 mean"s score of student questionnaire results on the use of task-based learning (TBL)

on the use of task-based learning (TBL) above, the data shows that students' perceptions of task-based learning on listening functional class in STBA Teknokrat are positive with an average value of 4 (Agree).

\subsection{Are Listening Skills in Functional Classroom} Listening Improved by Task-Based Learning (TaskBased Learning)

The analysis of whether listening skills on functional class listening increases with Task- Based Learning or not can be illustrated in the following table:

Table 4.2 .Test of Paired sample test in Cycle I and Cycle II

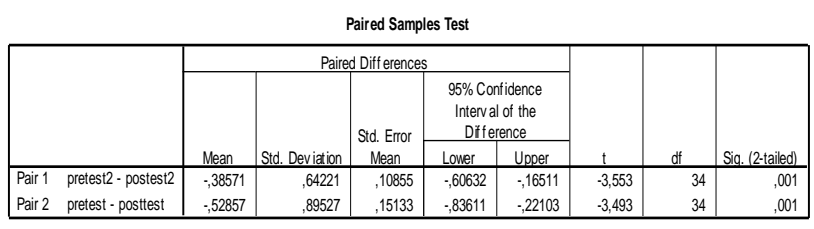

*) The increase is considered significant since the significance (2-

tailed) of both pairs below $\alpha(0.05)$

The above data shows that 2 tailed on pre-test and post test is $(, 001)$. This indicates that listening skills on functional class listening increased significantly. The average value of listening in cycles 1 and 2 is illustrated in the table below:
Table 5.3. Mean Score of Studentse Listening Comprehension Cycle I and Cycle II

\section{Paired Samples Statistics}

\begin{tabular}{|cc|c|r|r|r|}
\hline & & & & \multicolumn{1}{c|}{$\begin{array}{c}\text { Std. Error } \\
\text { Mean }\end{array}$} \\
\hline Pair 1 & pretest & 6,8943 & 35 & 1,21436 &, 20526 \\
& posttest & 7,4229 & 35 &, 94374 &, 15952 \\
\multirow{2}{*}{ Pair 2 } & pretest2 & 7,7486 & 35 &, 93851 &, 15864 \\
& postest2 & 8,1343 & 35 &, 81491 &, 13775 \\
\hline
\end{tabular}

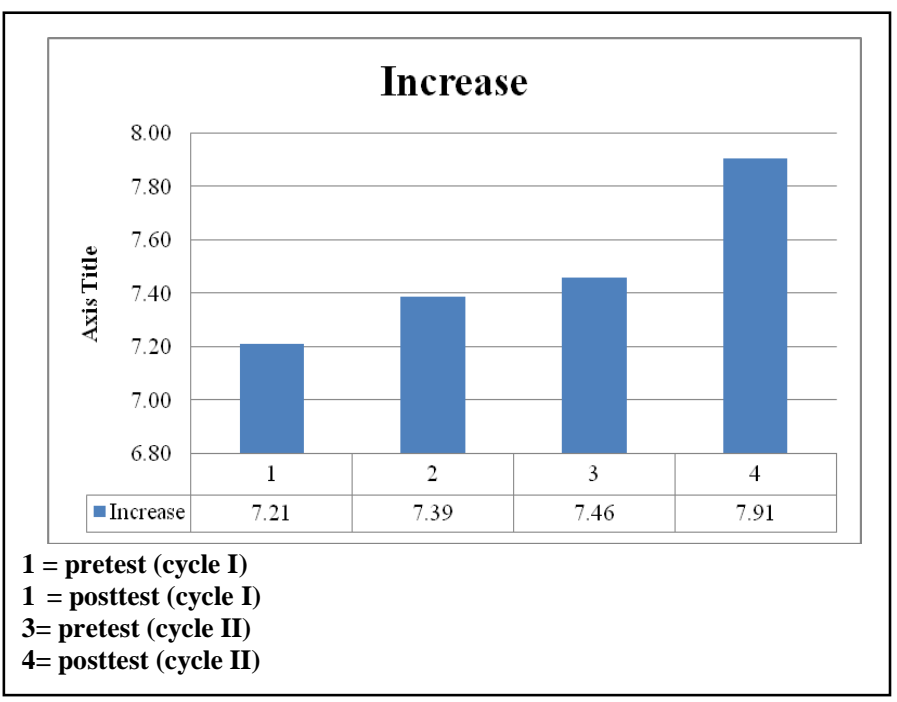

Chart 4.4 .The Increase of Students Listening Comprehension between Cycle I and Cycle II

Chart $4 . .4$ shows the average increase in pre-test (cycle 1) and post-test (cycle 1) ie from 7.21 to 7.39 in the second cycle also increased from 7.46 to 7.91 .

\section{CONCLUSION}

Based on the theoretical basis and supported by data analysis of test results of research instruments, it can be concluded as follows.

1. Students' perceptions of task-based learning on listening functional classes in STBA Teknokrat are positive.

2. Listening skills in listening functional class increased significantly with task-based learning that is average on pre-test (cycle 1) and post-test (cycle 1) that is from the value of 7.21 to 7.39 and on the second cycle also experienced an increase that is from 7.46 to 7.91. 


\section{Acknowledgment}

The authors are in debt to the students and lecturer who participated in this study. The main author also acknowledged the contribution of the fund provider from Republic of Indonesia Ministry of Research, Technology and Higher Education, under Penelitian Dosen Pemula (PDP) Grant Scheme.

\section{References}

[1] Arikunto, S, Suhardjono \& Supardi, Penelitian Tindakan Kelas. Jakarta: PT Bumi Aksara, 2015.

[2] Flowerdew, J \& Miller, L.. Second Language Listening: Theory and Practice. USA: Cambridge University Press, 2005.

[3] Nahavandi, Naemeh. The Effect of Task-based Activities on EFL Learners' Reading Comprehension. "Advances in Language \& Literrary Studies” 2 No.1, January 2011.

[4] Nunan, David, Practical English Language Teaching. Singapore: Mc Graw Hill, 2003.

[5] Promruang, Jipada, "The use of Task Based Learning to improve English Listening and speaking abilities of Mattayomsuksa 1 students at Piboonprachasan School”. Thesis (Unpublished). Bangkok: Srinakharinwirot University, 2012.

[6] Rahbar, S. \& Khodabakhsh, S., English songs as an effective asset to improve listening compsprehension ability; evidence from Iranian EFL Learners. International Journal of applied
Linguistics \& English literature, Vol.2 No.6; November 2013.

[7] Rianasari, Task-Based Language Teaching (TBLT) dalam Pembelajaran Menulis Surat Niaga berbahasa Inggris, 2012.

[8] Richards, J \& Theodore, S, Approaches and Methods in Language Teaching. UK: Cambridge University Press, 2001.

[9] Ruso, Nazenin. "The Influence of Task Based Learning on EFL Classrooms." Asian EFL Journal No.18, February 2007, pp 1-23.

[10 Sarani, et al. The Effect of Video-Based Tasks in Listening Comprehension of Iranian PreIntermediate EFL Learners. "Gist Education and Learning Research Journal” No. 8, January - June 2014. pp. 29-47.

[11] Sugiyono, Metode Penelitian Pendidikan. Bandung: Alfabeta, 2009.

[12] Tarigan, Henry Guntur, Menyimak sebagai Suatu Keterampilan Berbahasa. Bandung : Angkasa, 1997.

[13] Willis, Jane. A Framework for Task-Based Learning. Harlow: Longman, 1996.

[14] Willis, Jane. A Framework for Task-Based Learning. Harlow: Longman, 2004.

[15] Willis, D. \& Willis J. Doing Task Based Teaching. New York: Oxford University Press, 2007. 